\title{
Communication Science Studies - Spoken Discourse Analysis Verbal Rhetoric and Leadership Style: A Comparative Study of Tun Dr. Mahathir Bin Mohamad and Dato' Sri Mohd Najib Tun Abdul Razak
}

\author{
Nur Fatmawati* \\ Postgraduate English Department \\ Universitas Mataram \\ Mataram Indonesia \\ nfatmawati06@gmail.com
}

\author{
Muhammad Amin \\ Postgraduate English Department \\ Universitas Mataram \\ Mataram Indonesia
}

\author{
Nawawi Nawawi \\ Postgraduate English Department \\ Universitas Mataram \\ Mataram Indonesia
}

\begin{abstract}
The inquiry on leadership communication is one of the most frequent research topics on leadership. Studies of leadership have become both appealing and demanding subjects since the act of leaders, their strategies will determine the future development of a state or country. Leadership is a behavior carried out by communication, in which communication clarifies perceptions of a leader's charisma. Communication style in relation to leadership becomes a relevant subject to discuss as it is one of the characteristics of highly effective leaders. This paper is a comparative study of verbal rhetoric and leadership styles between two non-western leaders, PM of Malaysia, Mahathir Mohamad and Najib Razak. The purpose of this study is to critically analyze the spoken discourse of the two Malaysian Prime Minister. This study employed a descriptive research design with a qualitative approach. This approach was applied to describe a language or discourse; sought to describe how language is used persuasively in speeches. This present study adopted Aristotle's three modes of persuasion, namely: providing facts (logos), appealing people's emotions (pathos) and projecting credibility (ethos). The primary data were taken from the video streaming website YouTube, while various sources such as Internet sites, journals, and books as secondary data were used to support the primary data. This study also utilized a historical approach purposefully to analyze the data according to the following year: 1982, 1995, 1996, 1997, 1998, $1999,2003,2018$, and 2019. The aim was to comparatively analyze how the two leaders formed and reflected their leadership styles during their tenure as Prime Minister through the use of verbal rhetoric. The research findings revealed that there are differences between Mahathir and Najib Razak in employing all three modes of persuasion.
\end{abstract}

Keywords - verbal rhetoric, leadership style, Mahathir Mohamad, Najib Razak

\section{INTRODUCTION}

Humans, as social creatures have a fundamental need to communicate. Most of human activities always related to speaking. Through communication they can express themselves, their thoughts, feelings or emotions, manage their social groups, environment, and develop a civilized culture. The skill of speaking and rhetoric might be related to one's aptitude or talent (a born-orator). An adequate speaking skill requires well-grounded knowledge and appropriate practices. Ironically, people often take good care or mind their ways of dressing but rarely mind or abandon their ways of speaking.

In societal and cultural life, speaking or rhetorical skill plays a vital role. Human relationship is built through communication. Thus, the act of speaking enables people to connect and thus, live together in harmony in various social orders. The role of rhetoric as a study of effective communication will provide us with some insights about the need for people to have this kind of skill to interact with others efficiently (i.e to achieve the aim of speaking). Studies of leadership have become both appealing and demanding subjects since the act of leaders, their strategies will determine the future development of a state or country. Thus, it is considered important to conduct extensive and thorough research regarding the rhetorical skill in relation to leadership style.

On all stages of the world, and in all stages of the past, we have seen leaders of all kinds give elaborately drafted speeches filled with cleverly written or crafted rhetoric, sometimes in response to an event, and sometimes as a custom or merely by obligation. Some of the leaders' words have captivated the masses, inspired nations, prompted movements, and even educated people who seek new ideas. In this case, the rhetoric of political leaders can be used to both teach and inspire.

Leaders provide purpose, direction, and motivation every day, and frequently this comes through the use of rhetoric in speech. Thus, leaders give purpose, provide direction, and inspire motivation within others to accomplish the mission. Therefore, the use of rhetoric is useful in leadership practice as a way to form a connection in the leader's communicative efforts in the micro or macroscope. Public discussion and debate are crucial in a democracy, and because leaders are obliged to rule the sovereign people through constant persuasion, rhetoric is thus a central subject to be enquired.

In this research, the researchers particularly chose Tun Dr. Mahathir Bin Mohammad and Dato' Sri Mohd Najib Tun Abdul Razak as my subject. There are four reasons for this choice, they are 1) Objectivity: it allows me to a certain degree to be objective since I don't have any direct experience of their leadership, personal traits, etc., 2) 
Model of strong leadership: consider Mahathir (also called Dr. M) as one of the best representatives of political leaders who has strong leadership influences, especially among the non-western leaders. Tun Mahathir has the longest tenure as the Prime Minister of Malay (i.e about 22 years), and now he serves as the $7^{\text {th }} \mathrm{PM}$, thus takes the position as the incumbent, and become the oldest leader in the world as well, whose being elected in the age of 92 . Thus, it indicates the strong leadership influences in terms of quality and quantity standards. 3) Time-efficiency: since we don't have to translate the script of the speeches into English because most of the speeches are already spoken and written in English - consider English as the L2 (second language) of Malaysian. Besides, the EPI (English Proficiency Index) of the Malay people is in the $5^{\text {th }}$ rank in Asia as compared to Indonesian's (the $32^{\text {nd }}$ rank). And 4) Source of learning regarding leadership practices across the Asian countries: it provides us insights into the leadership styles and strategies (i.e. specifically the nonwestern leaders). Thus, we can make use of the research findings as a reference for us to comparatively studying the leadership styles and verbal rhetoric used among ASIAN leaders.

\section{REVIEW OF THE PREVIOUS STUdIES}

Comparative studies of leadership styles and rhetoric, either western or non-western leaders have been conducted by many researchers due to its urgent and fascinating nature as a research topic. In his research, Savoy examined the style and rhetoric of the two main candidates, Hillary Clinton and Donald Trump during the 2016 presidential election [1]. This study revealed that based on interviews and TV debates, the most frequent lemmas indicate an emphasis on the pronoun "I" for both candidates. Whereas, in speeches, the pronoun "we" appears more frequently. Also, based on overall stylistic indicators, Trump adopts a simple and direct communication style, preferring short sentences, avoiding complex formulations and employing a reduced vocabulary. In the oral form, Trump frequently uses verb phrases (verbs and adverbs) and pronouns while Clinton is more descriptive (more nouns and prepositions). According to predefined word lists, this study indicated that Clinton's rhetoric employs more cognitive words, while negative emotions and exclusive terms occur more frequently in Trump's verbiage.

Sulistiyani, Dwi., Mukaroma carried out a comparative analysis of rhetoric between the two former President of Indonesia, Susilo Bambang Yudhoyono and Joko Widodo (Gaya Retorika Kepala Negara RI: Analisis Komparatif Susilo Bambang Yudhoyono dan Joko Widodo) [2]. This study used the theory of both verbal and non-verbal codes. The results of this study showed that SBY tends to use formal language (langue) rather than informal (parole) compared to Jokowi. Thus, Jokowi adopts a simple and direct communication style, thus avoiding complex formulations (i.e. using a more casual or informal language). While SBY is more organized and descriptive. Other qualities that support Jokowi's persuasive communication is his distinct non-verbal communication style (i.e. body language and mimic).

Ricky conducted comparative research of rhetorical style between the two main candidates, Prabowo and
Jokowi during the 2014 presidential election [3]. The findings revealed that there are differences between Prabowo and Jokowi in employing all three modes of persuasion: ethos, pathos, and logos. 1) the Ethos of Prabowo in his speech - he appeared to be assertive, directive, and authoritative in his manner, whereas Jokowi seemed to be simple, hard-working, and patient. 2) the Pathos of Prabowo - he emphasized his speech on the data that have been obtained from the Indonesian AntiCorruption Commission (KPK), while Jokowi used his former experiences 'Blusukan' to convince and gain the people or public citizen's trust. the Logos of Prabowo - his arguments were based on the information obtained from the Indonesian Anti-Corruption Commission (KPK), whereas Jokowi used his former experiences in developing the economy and health system during his time leading the 'DKI Jakarta' (i.e. Governor of DKI) as his logical proofs to the public citizens [3].

This present study differs from those of the previous studies in that this study focuses on the Prime Minister as the subject of research, while the three researchers were concern about analyzing leadership styles and rhetoric of the President or main candidate in the Presidential election. The objective of this research is to comparatively study leadership styles and verbal rhetoric between the two nonwestern leaders, Prime Minister of Malaysia (Dr. Mahathir and Najib Tun Abdul Razak). The analysis of this study was emphasized on the three modes of persuasion proposed by Aristotle that are: ethos (the character of the orator), pathos (the emotional state of the listener), and logos (the argument itself).

\section{METHOD}

The research was conducted to gain insight into how a leader's communication styles through the use of verbal rhetoric determine his effectiveness in persuading his followers to accomplish his mission. The purpose of the study is to critically analyze the spoken discourse of the two non-western leaders, Prime Ministers of Malaysia, Dr. Mahathir and Najib Razak (i.e. to compare their leadership styles through examining their verbal rhetoric). This study employed a descriptive research design with a qualitative approach. This approach was applied to describe a language/discourse, and to describe how a leader's verbal rhetoric reflecting their leadership styles.

The data for the discussion related to the two nonwestern leaders, Dr. Mahathir's and Najib Razak's speeches were downloaded from the video streaming website of YouTube: Full frontal. About 102 videos containing the speeches of Dr. Mahathir and 14 for Najib Tun Abdul Razak. These videos were selected based on certain criteria, such as: (1) it contains issues of both national and international policies, (2) it is spoken or written in English (i.e. Speeches which are spoken or written in the Malay language are excluded). These selected videos thus were used as primary data, while various sources such as Internet sites, journals, and books as secondary data were used to support the primary data.

The selected videos from YouTube containing speeches of both PM of Malay then were analyzed by employing the three modes of persuasion proposed by Aristotle: ethos (the character of the orator), pathos (the 
emotional state of the listener), and logos (the argument itself). Also, this analysis used a historical approach to analyze the data according to the year the speeches were made. The analysis was separated according to the following year: 1982, 1995, 1996, 1997, 1998, 1999, 2003, 2018, and 2019. The aim was to comparatively analyze how the two non-western leaders, Dr. Mahathir and Najib Razak form and reflect their leadership styles during their tenure as Prime Minister through the use of verbal rhetoric. The following table illustrated the analytical framework of this study:

TABLE I. THREE MODES OF PERSUASION

\begin{tabular}{|c|c|}
\hline Rhetorical device & Characteristics \\
\hline Logos (Logical mode) & $\begin{array}{l}\text { Logos can be seen through the } \\
\text { speaker's: reasons, facts, evidence, } \\
\text { examples, statistics, rhetorical } \\
\text { questions, syllogism, enthymemes, } \\
\text { and statements from authorities as } \\
\text { proofs, and eye-witnesses - to } \\
\text { reach a valid conclusion. }\end{array}$ \\
\hline \multirow[t]{4}{*}{ Ethos (Ethical mode) } & $\begin{array}{l}\text { Ethos is embedded in the } \\
\text { messages sent by the speaker. It } \\
\text { can be seen through the speaker's } \\
\text { credibility. } \\
\text { The speaker can achieve his } \\
\text { credibility when he reflects in his } \\
\text { messages the qualities of: } \\
\text { 1) Good sense. This can be done } \\
\text { when the speaker: } \\
\text { - demonstrates that he is } \\
\text { competent } \\
\text { - knowledgeable about the } \\
\text { addressed issue } \\
\text { - illustrates that he is } \\
\text { clearheaded } \\
\text { - well-informed }\end{array}$ \\
\hline & $\begin{array}{l}\text { 2) Good moral character } \\
\text { (manifesting beliefs and } \\
\text { values). The speaker should be: } \\
\text { - even-handed and unbiased } \\
\text { - straightforward } \\
\text { - reasonable }\end{array}$ \\
\hline & $\begin{array}{l}\text { 3) Goodwill. The speaker: } \\
\text { - shows that he is sincere } \\
\text { - shows that he is concerned } \\
\text { about the welfare of others }\end{array}$ \\
\hline & $\begin{array}{l}\text { - wishes to others what is good } \\
\text { for them }\end{array}$ \\
\hline $\begin{array}{l}\text { Pathos (Emotional } \\
\text { mode) }\end{array}$ & $\begin{array}{l}\text { Pathos is a persuasive means } \\
\text { based on emotion. In pathos, the } \\
\text { speaker attempts to: } \\
\text { - stir the hearer's emotions } \\
\text { - make the listener experience a } \\
\text { specific kind of feeling that } \\
\text { coincides with the ongoing } \\
\text { situation. } \\
\text { - arouse feelings such as empathy, } \\
\text { anger, sorrow, compassion, fear, } \\
\text { love, pride, etc. }\end{array}$ \\
\hline
\end{tabular}

\section{RESULTS AND DISCUSSION}

The following table shows how logos, ethos, and pathos are employed differently by the two non-western leaders, Mahathir and Najib Razak.

TABLE II. LOGICAL, EMOTIONAL AND ETHICAL MODES UTILIZED BY DR. MAHATHIR MOHAMAD

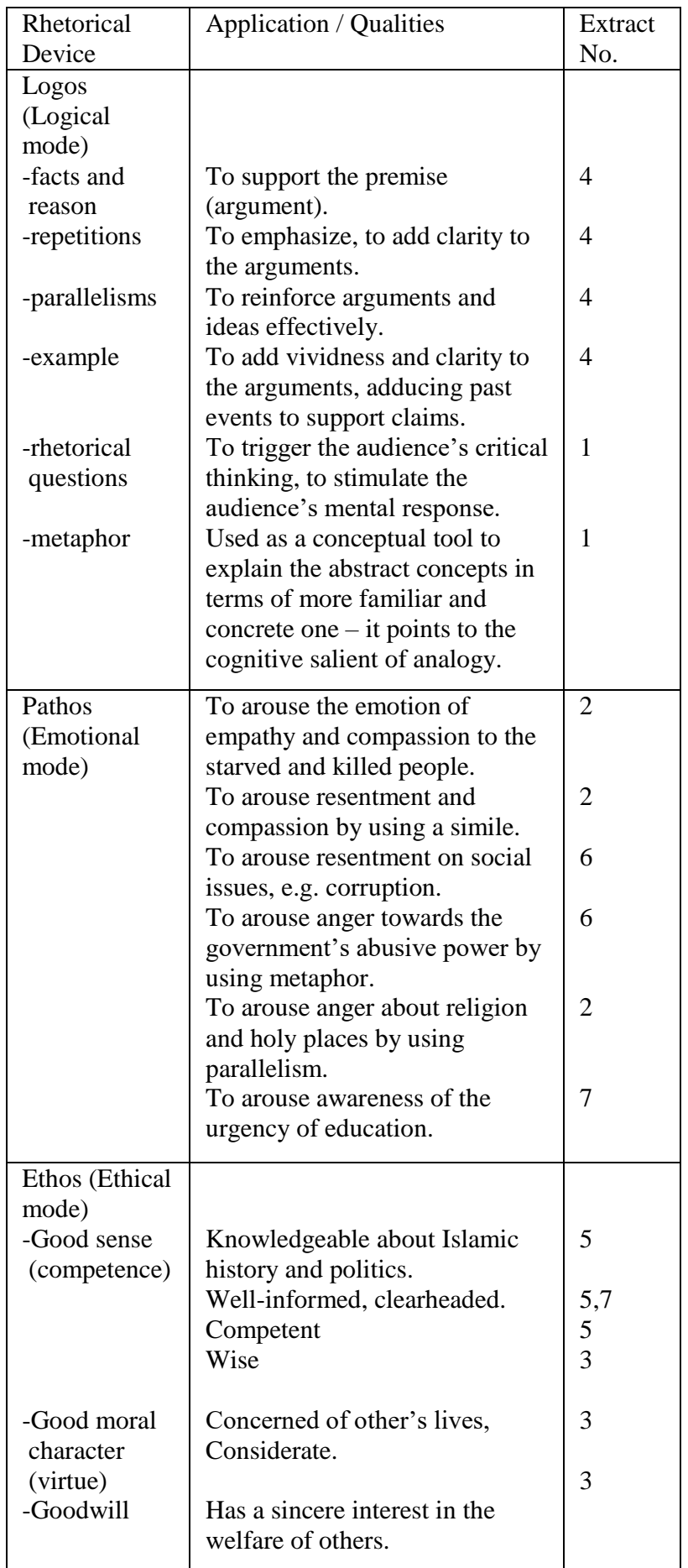

The findings showed that the application of the rhetorical devices by Dr. Mahathir was generally linked to socio-political issues such as Islam and terrorism, wars, the situation of the Muslim world, domination by the West, and abuse of power (corruption). Thus, they were 
associated with ongoing social events. The way he addressed these socio-political issues indicated that ethos is the most important element in his discourse. The central rhetorical device in Mahathir's spoken discourse was laid on his ethos.

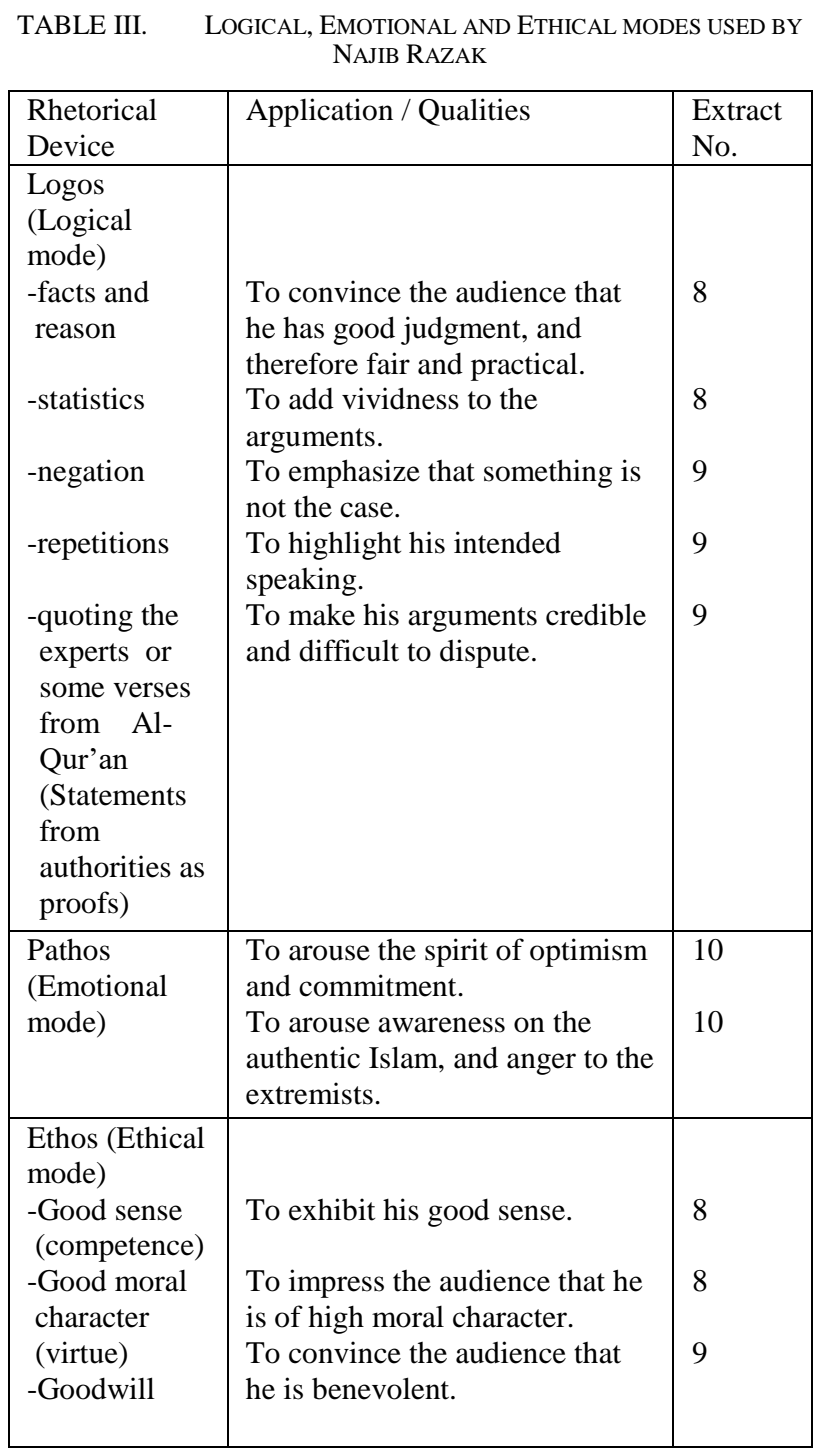

Conversely, Najib's spoken discourse indicated that logos is the strong element used as a persuasive tool compared to Dr. Mahathir that lies on ethos. In Mahathir's verbal rhetoric, ethos is projected through his logos and pathos. For instance, in extract 2 when he addressed the situation of the Muslim world, he displayed his good sense and expertise to assess the circumstances of the Muslim world, providing instructions and resolutions that reflected his ethos. As logical proof, he argued that the attribution of the bad situation of the Muslim world was caused by illiteracy, poor education, the weakness of Muslims in science, technology and economy and the misinterpretation of Islam.

Ethos refers to the character attributed to a speaker by listeners based on what the speaker says and does in speech [4]. From the data above, it was found that Mahathir's ethical proof was not stated explicitly but was embedded in his logical and emotional evidence. His messages and arguments implicitly indicated him as wellinformed, competent, clearheaded, and concerned about people's welfare (Extract 5 and 7).

It was found that Najib's salient rhetorical element is his logical evidence (logos). As has been shown above that logos tends to appear more frequently in his speeches. His logical proof was supported by the use of various rhetorical devices such as facts and reasons, statistics, negation, repetitions, and statements from authorities such as the expert's quotes and Al-Qur'an verses to make his arguments credible and difficult to dispute. Thus, the data showed that it is logos that matter most in Najib's persuasive speeches. In Mahathir's discourse, on the other hands, ethos is the central device or the strongest element, i.e. through his ethos he project his goodwill, showing that he is not self-centered or thinks and acts in terms of what is good for him or his community (i.e. is not think and act based on self-interest but people or citizens interest). As Prof. Dr. Ing. H. Bacharuddin Jusuf Habibie once said "Without love, intelligence is meaningless or even dangerous. And without intelligence, love is not enough". Herein, we can describe love as leader's sincere attempts to serve the country well, to establish a set of policy that sounds right or reasonable and to lead with integrity and character (i.e. to be genuine or authentic in ruling the country). Thus, it is a leader's ethos that plays a fundamental role in determining his effectiveness as a leader. Ethos is the core of leadership, and the absence of ethos will cause a leader losing the right track in leading the country.

According to Aristotle, there are three core qualities for an orator to create his ethical proofs (ethos) for persuasion: good sense, virtue, and goodwill. Thus, for the speakers can manage to appear a credible person, he must: (1) he must display practical intelligence (good sense), (2) he must have a virtuous character (virtue), and (3) he must have goodwill. In this case, for speakers are wrong both in what they say and the advice they give, because they lack either all three or one of them. Thus, for either through want of sense they form incorrect opinions, or if their opinions are correct, through viciousness they do not say what they think, or if they are sensible and good, they lack goodwill; therefore, it may happen that they do not give the best advice, although they know what it is. These qualities thus are all that is necessary, so the speakers appear to possess all three will necessarily convince the hearers.

\section{CONCLUSION}

Crises in various sectors have led us into thinking about the leaders' role as they are expected to react to the situations and need to communicate about the events to the public citizens. One of the factors that have a significant impact on the ability to successfully respond to the situation is dependent on the rhetorical skill of the leader. Conversational skill or competence in communication will make a difference in one's success in emerging as an effective leader. Rhetoric is never simply the transmission of information, rather it is the interpretation of information. From the data result and discussion, we can conclude that ethos that dominates in Mahathir's persuasive speeches, while Najib's lies on his logical evidence (logos). 
And on to my final point, it is merely ethos that matters, not logos for a leader to keep on the right track in governing the country. Thus, when a leader's head and heart connect in both, he will less likely to be abusive in leading the government. A good leader is expected to grow like a tree, not grass. A tree grows slowly but takes time to die (even perhaps endured, since the fallen seeds will grow and duplicate themselves). Grass, on the other hand, it grows quickly and also withers up quickly. This analogy would best suit an indicator of great leadership - a great leader has to have an impact that lasts long for others; thus his beneficial actions or policies must not be a temporary thing (i.e. long-lasting legacy, in this case, is his wisdom). It is important that leaders in running the government to have ethos, pathos, and logos which is genuine or authentic in a way that shows his understanding of the societal problems, willingness to deal with tough situations by leading people with integrity, not through abuse of power or deceitful action (kleptocracy). As a matter of fact, this has been proven by Dr. Mahathir, in which he has succeeded in becoming the incumbent at the 2018 general election, thus being reelected as a PM

\section{REFERENCES}

[1] Savoy, Jacques. Trump's and Clinton's Style and Rhetoric during the 2016 Presidential Election. Switzerland: Routledge, 2017.

[2] Sulistiyani, Dwi., Mukaromah. Gaya Retorika Kepala Negara RI: Analisis Komparatif Susilo Bambang Yudhoyono dan Joko Widodo. Semarang: Universitas Dian Nuswantoro, 2017.

[3] arefsky, D. Public Speaking: Strategies for Success $\left(5^{\text {th }}\right.$ ed). Boston: Pearson Education, Inc, 2008.

[4] Campbell, K.K. Critiques of Contemporary Rhetoric. Belmont: Wadsworth Publishing Company, 1972.

[5] Roberts, W.R. Rhetoric by Aristotle. Ebooks@Adelaide. The University of Adelaide Library, South Australia. Retrieved from http://ebooks.adelaide.edu.au/a/aristotle/a8rh/complete. html, 2007. 